\title{
Effect of Perception of Facilities, Intensity of Conduct, and Satisfaction of Tax Payers to Submission of Letter by E-Filing Notice on Tax Service
}

\author{
Muammar Khaddafi
}

Faculty of Economics, Department of Accounting, Universitas Malikussaleh, Lhokseumawe, Aceh, Indonesia

Henry Aspan

Faculty of Economics, Department of Management, Universitas Pembangunan Panca Budi, Medan, Indonesia

Mohd. Heikal, Wahyuddin, Falahuddin and ZatinHumaira Faculty of Economics, Department of Accounting, Universitas Malikussaleh, Lhokseumawe, Aceh, Indonesia

\begin{abstract}
Purpose - The purpose of this research is to determine the effect of perceived ease, intensity of behavior, and user satisfaction in using the e-filing system, especially in the city of Lhokseumawe.

Design/Methodology/Approach - Analysis of the data in this study was done using multiple linear regression. The sample collection method used in this study was convenience sampling with a total sample of 96 people.

Findings - The results showed that (Aditya, 2011) perceived ease had a positive significant effect on the use of e-filing (Ajzen, 1980), intensity behavior positive significant effect had a on the use of e-filing (Darussalam, 2007), and user satisfaction had a positive significant effect on the use of e-filing (Davis, 1989).

Research Limitations/Implications - The implication of this research is the effect of user satisfaction against use of e-filing.

Practical Implications - Use of e-filing can simplify the reporting process overall by taxes and easy to use e-filing.

Originality/Value - Perceived ease, intensity behavior, and user satisfaction affect the use of e-filing.

Keywords E-filing, perceived ease, intensity behaviour, satisfaction taxpayer

All papers within this proceedings volume have been peer reviewed by the scientific committee of the Malikussaleh International Conference on Multidisciplinary Studies (MICoMS 2017).
\end{abstract}

(C) Muammar Khaddafi, Henry Aspan, Mohd. Heikal, Wahyuddin, Falahuddin, ZatinHumaira. Published in the Emerald Reach Proceedings Series. Published by Emerald Publishing Limited. This article is published under the Creative Commons Attribution (CC BY 4.0) licence. Anyone may reproduce, distribute, translate and create derivative works of this article (for both commercial and non-commercial purposes), subject to full attribution to the original publication and authors. The full terms of this licence may be seen at http://creativecommons.org/licences/by/4.0/legalcode
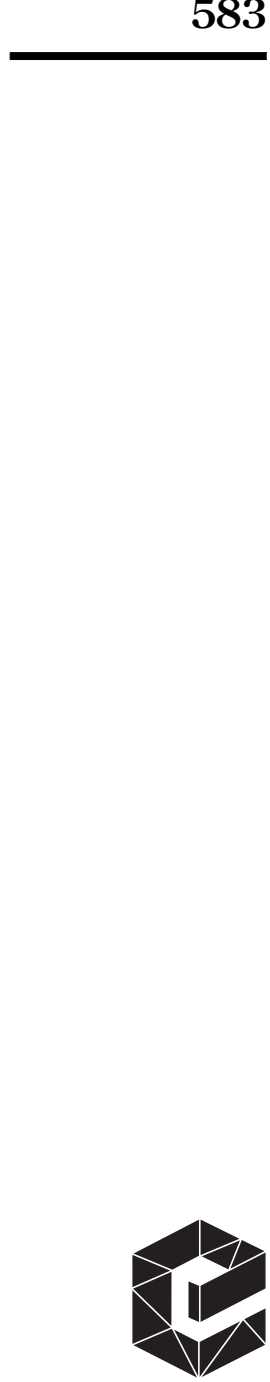


\section{Proceedings of 1. Introduction}

MICoMS 2017 State revenues from the tax sector in the country is the most popular form of revenue generation for the country, because the tax is an instrument of the state that has an important role in sustaining state financing. The size of the revenues from tax will be largely determined by the level of tax compliance. When state revenues from other sectors experienced a decreased tendency, expectations for tax revenue is increasingly urgent.

Answering and addressing the growing needs of the community of taxpayers throughout Indonesia will be a level of service that should be getting better, with the ballooning cost of processing tax returns and the desire to reduce the burden of administrative processes using paper tax returns. Then Director General of Taxes in meeting the aspirations of the taxpayer issued a decision of the Director General Tax No. KEP-88/PJ./2004 dated May 14, 2004 (BN No. 7069 Page. 4B) of the Notice of Submission and Submission of Notice of Extension in Electronics. After the success of e-SPT program then the Directorate General of Taxation (DGT) issued a decree back KEP-05/PJ/2005 are set out on January 12, 2005 on the submission of the notice electronically (e-filing) through an Application Service Provider (ASP) appointed by the Director General of Taxation.

However, in practice, this system is not an easy thing to implement. That is because the system is still new so there are still shortcomings and still many things that need to be understood related to the readiness of human resources, facilities, and devices that need a process and a long time. Besides, this must follow the development of Information Technology. On the side of the taxpayer, what may happen is the lack of ability to synchronize data formats available to him with the data format desired by the system ASP and the DGT system. Therefore, taxpayers are expected to be cautious and should really know about how to use the e-filing system.

Research conducted by Pratt (2008), Heikal et al. (2014) reveals that user behavior and system personnel required in the development of the system, and this is related to the understanding and perspective for users of the system. Implementation of a system and information technology cannot be separated from the behavioral aspects related to the development of systems for individual and organizational problems as users of the system, so the system should be oriented to the users.

Currently, not all taxpayers to use e-filing because taxpayers still think that the use of computer systems in the reporting of the notification letter is very confusing and difficult than manually. This is because there are many taxpayers who do not understand about the operation of e-filing and the ability of taxpayers to use e-filing is still minimal. In addition, the socialization of e-filing to taxpayers is not maximized and sustained. Whereas reporting computerized notification has greater benefits for the taxpayer and the DGT. Based on the description above, the issues to be examined in this study are as follows (Aditya, 2011): Is the effect on perceived ease of use of e-filing (Ajzen, 1980)? Does the intensity of behavior affect the use of e-filing (Darussalam, 2007)? Is user satisfaction affect the use of e-filing (Davis, 1989)? and Is the ease of perception, the intensity of the behavior, and user satisfaction together affect the use of e-filing?

\section{Formulation of the problem}

H1: Perceived ease significantly positive effect on the use of e-filing.

H2: The intensity of conduct significantly positive effect on the use of e-filing.

H3: User satisfaction significantly positive effect on the use of e-filing.

H4: Perceived ease, intensity behavior, and user satisfaction significantly positive effect on the use of e-filing. 


\section{Method}

\subsection{Population and sample}

The population in this study are all Taxpayers who use e-filing in the city of Lhokseumawe.

The sampling method used in this study are non-probability convenience sampling. Convenience sampling is a method of sampling is done by selecting a sample freely by the researcher. The sample in this study is the individual taxpayer in the city of Lhokseumawe who never reported a notice via e-filing.

Analysis of the data used to test the hypothesis in this study is to use multiple linear regression model with the following equation:

$$
P E=\alpha+\beta_{1} P K+\beta_{2} I P+\beta_{3} K P+\mathrm{e}
$$

where, $\mathrm{PE}$ is the use of e-filing; $\mathrm{PK}$, the perceived ease; IP, the intensity of conduct; $\mathrm{KP}$, the user satisfaction; A, constants; B, regression coefficients; e, coefficient error.

\section{Results and discussion}

\subsection{Research result}

The method is performed in a reliability test is to see Cronbach alpha values shown in Table 1.

Reliability of a construct can be judged from the Cronbach's alpha. If the magnitude of Cronbach's alpha above 0.60 then the construct can be said to be reliable (Ghozali, 2011). Table 1 shows that all constructs are reliable.

The method is performed in testing the validity is to look at the Pearson correlation of each indicator variable for each question shown in the Table 2 .

If the correlation between the scores of each of the questions with a total score has a significance level below 0.05 then the questions are considered valid and vice versa (Ghozali, 2011). It can be concluded that all the independent indicator variables in the Table 2 above are valid.

\subsection{Discussion}

Testing this hypothesis using a regression test and the results are presented in Table 3.

The results of testing the first hypothesis $\left(H_{1}\right)$ stated perceived ease affect the use of e-filing with $t$-value of 3.428 with a significance of 0.001 , while the value t table at $\alpha=0.05$ obtained a value of 1.66159 means that $\mathrm{t}$ is greater than $t$ table. Then the decision accept $H_{1}$, which means that the perceived ease significantly positive effect on the use of e-filing. This shows that the perception of the ease of clear, incomprehensible, and easy to be skilled in the use of e-filing.

Results of testing the second hypothesis $\left(H_{2}\right)$ stated that intensity behavioral affect the use of e-filing with $t$ value of 2.560 with a significance value is 0.012 , while the value $t$ table at $\alpha=0.05$ obtained a value of 1.66159 means that $t$ is greater than $t$ table. Then the decision

\begin{tabular}{lcccc}
\hline No. & Variables & Total Indicator & Value Alpha & Description \\
\hline 1. & Perceived ease (PK) & 5 & 0.712 & Reliable \\
2. & Intensity behavior (IP) & 5 & 0.757 & Reliable \\
3. & User satisfaction (KP) & 5 & 0.642 & Reliable \\
4. & The use of e-filing (PE) & 5 & 0.763 & Reliable
\end{tabular}

Source: Research (processed) 2014.

Table 1. Reliability Test

\section{E-Filing Notice}


Proceedings of MICoMS 2017
Indicator Variable Question

Independent and Dependent

\begin{tabular}{lll}
\hline PKX $_{1}$ & $0.611^{* *}$ & Valid \\
PKX $_{2}$ & $0.576^{* *}$ & Valid \\
PKX $_{3}$ & $0.757^{* *}$ & Valid \\
PKX $_{4}$ & $0.758^{* *}$ & Valid \\
PKX $_{5}$ & $0.676^{* *}$ & Valid \\
IPX $_{1}$ & $0.756^{* *}$ & Valid \\
IPX $_{2}$ & $0.703^{* *}$ & Valid \\
IPX $_{3}$ & $0.793^{* *}$ & Valid \\
IPX $_{4}$ & $0.791^{* *}$ & Valid \\
IPX $_{5}$ & $0.515^{* *}$ & Valid \\
$\mathrm{KPX}_{1}$ & $0.714^{* *}$ & Valid \\
$\mathrm{KPX}_{2}$ & $0.731^{* *}$ & Valid \\
$\mathrm{KPX}_{3}$ & $0.715^{* *}$ & Valid \\
$\mathrm{KPX}_{4}$ & $0.540^{* *}$ & Valid \\
$\mathrm{KPX}_{5}$ & $0.503^{* *}$ & Valid \\
$\mathrm{EPY}_{1}$ & $0.670^{* *}$ & Valid \\
$\mathrm{EPY}_{2}$ & $0.789^{* *}$ & Valid \\
EPY $_{3}$ & $0.676^{* *}$ & Valid \\
EPY $_{4}$ & $0.785^{* *}$ & Valid \\
$\mathrm{EPY}_{5}$ & $0.650^{* *}$ & Valid
\end{tabular}

Source: Results (Data processed in 2014).

Correlation is significant at the 0.01 Level (2-tailed)

Table 2.

Validity Indicator Variables
$\mathrm{PKX}_{1}, \mathrm{PKX}_{2}, \mathrm{PKX}_{3}, \mathrm{PKX}_{4}, \mathrm{KPX}_{5}=$ Perceived ease of indicators $\mathrm{X}_{1}, \mathrm{X}_{2}, \mathrm{X}_{3}, \mathrm{X}_{4}, \mathrm{X}_{5}$.

$\mathrm{IPX}_{1}, \mathrm{PKX}_{2}, \mathrm{PKX}_{3}, \mathrm{PKX}_{4}, \mathrm{KPX}_{5}=$ Intensity behaviors for indicators $\mathrm{X}_{1}, \mathrm{X}_{2}, \mathrm{X}_{3}, \mathrm{X}_{4}, \mathrm{X}_{5}$.

$\mathrm{KPX}_{1}, \mathrm{PKX}_{2}, \mathrm{PKX}_{3}, \mathrm{PKX}_{4}, \mathrm{KPX}_{5}=$ User satisfaction for indicators $\mathrm{X}_{1}, \mathrm{X}_{2}, \mathrm{X}_{3}, \mathrm{X}_{4}, \mathrm{X}_{5}$.

$\mathrm{EPY}_{1}, \mathrm{PKY}_{2}, \mathrm{PKY}_{3}, \mathrm{PKY}_{4}, \mathrm{KPY}_{5}=$ User e-filing for indicators of $\mathrm{Y}_{1}, \mathrm{Y}_{2}, \mathrm{Y}_{3}, \mathrm{Y}_{4}, \mathrm{Y}_{5}$.

receiving $\mathrm{H}_{2}$, which means the intensity of behavior significantly positive effect on the use of e-filing. The intensity of this behavior where users feel happy, comfortable, motivated, interested, and conditioned for the use of e-filing.

The third hypothesis testing results $\left(H_{3}\right)$ states user satisfaction affect the use of e-filing with $t$ value for 2.073 with a significance value is 0.041 , while the value $t$ table at $\alpha=0.05$ obtained a value of 1.66159 means that $t$ is greater than $t$ table. So that means the decision receives $H_{4}$ user satisfaction significantly positive effect on the use of e-filling. System e-filing

Table 3.

Results of Multiple Linear Regression Analysis

\begin{tabular}{lrrr}
\hline Variable Name & $B$ & $t_{\text {count }}$ & Sig $(t)$ \\
\hline Constants & 14.920 & 6.305 & 0.000 \\
Perceived ease (PK) & 0.331 & 3.428 & 0.001 \\
Intensity behavior (IP) & 0.183 & 2.560 & 0.012 \\
User satisfaction & 0.172 & 2.073 & 0.041 \\
The correlation coefficient $(R)=0.416$ & & & \\
The coefficient of determination $\left(\mathrm{R}^{2}\right)=0.173$ & & \\
Adjusted $\left(R^{2}\right)=0.146$ & & \\
$F_{\text {count }}=6.401$ & & & \\
$F_{\text {table }}=2.70$ & & \\
Sig. $(F)=0.000$ & & & \\
$t_{\text {table }}=1.66159$ & & & \\
Source : Research (Data processed in 2014). & & &
\end{tabular}


effectively meet the needs of users associated with tax reporting, users were satisfied with the service of e-filing, e-filing system can help tax reporting efficiently, users have a pleasant experience in using e-filing, and users feel pride in using the e-filing system.

The results of testing the fourth hypothesis $\left(H_{4}\right)$ stated that perceived ease, intensity behavior, and user satisfaction affect the use of e-filing with the value of $F$ for 6401 with the significant value of 0.001 at the level of $95 \%$. While the $F$ table obtained a value of 2.70 at $\alpha=0.05$. Thus $F$ count $>F$ table is $6401>2.70$ and significant value of $0.001<0.05$. From the results of the $F$ test this means accepting $H_{4}$. Thus the perception of ease, the intensity of the behavior, and user satisfaction significantly influence the use of e-filing. Judging from the indicators in which the user wishes to continue using e-filing in the future, always use e-filing for tax reporting because it has features that help the user work, always try to use e-filing tax reports every time, use of e-filing can simplify the reporting process overall my taxes, and easy to use e-filing.

\section{Conclusion}

Based on the research, it can be concluded that perceived ease, intensity behavior, and user satisfaction affect the use of e-filing.

\section{References}

Aditya, F. (2011). The Effect of Information Systems Quality, Perceived Ease of Use, and Perceived Usefulness Accounting Software User Satisfaction. Thesis Faculty of Social Sciences and Economics, University of Yogyakarta, Yogyakarta.

Ajzen, I. and Fishbein, M. (1980). Understanding Attitudes and Predicting Social Behavior. Prentice Hall, New Jersey.

Darussalam, D. (2007), "The New Face of Quality Service Directorate General of Taxes” https://www. google.co.id/search?dcr=0\&ei=AJzIWoaHEozbvgT9opDACQ\&q=Darussalam \%2C+D+2007 +Taxes\&oq=Darussalam\%2C+D+2007+Taxes\&gs_l=psy-ab.12..32572.34253.0.36509.6.6.0.0. 0.0.202.947.0j3j2.5.0.......1c.1.64.psy-ab..1.3.549...33i22i29i30k1j33i21k1j33i160k1.0.mz-hy WgnNd8 [accessed 20 June 2014].

Davis, F.S. (1989). "Perceived Usefulness, Perceived Easy of Use, and Acceptance of Internet Tehnology by Consumers". Proceedings of the 37th Hawaii International Conference on System Sciences, Universitat Trier, Maui.

Ghozali, I. (2011). Multivariate Analysis Applications with IBM SPSS 19. Publisher Agency Diponegoro University: Semarang.

Heikal, M., Khaddafi, M. and Falahuddin (2014). "The Intention to Pay Zakat Commercial: An Application of Revised Theory of Planned Behavior". Journal of Economics and Behavioral Studies, Vol. 6, No. 9, pp. 727-734.

\section{Corresponding author}

Muammar Khaddafi can be contacted at khadafi@unimal.ac.id 